\title{
Original
}

\section{Improved Photobactericidal Activity of Ultraviolet-A Light in Combination with Isomerizable $p$-Coumaric Acid Derivatives}

\author{
AKIHIRO SHIRAI* , MASATO KAJIURA, KYOHEI MATSUMURA, AND TAKESHI OMASA \\ Department of Biological Science and Technology, Biosystems Engineering, Institute of Technology and \\ Science, Tokushima University, 2-1 Minamijosanjima-cho, Tokushima 770-8506, Japan \\ Received 12 February, 2015/Accepted 23 May, 2015
}

\begin{abstract}
In order to improve the photobactericidal activity of ultraviolet-A (UV-A) mediated by reactive oxygen species (ROS), the present study focused on trans-coumaric acid (trans-CA), which is isomerized by UV-A. Generation of ROS was expected during the isomerization of trans-CA. Trans-CA derivatives, in which the carboxyl group was modified with a methyl, $n$-butyl or phenyl group, thereby changing the interaction with the cellular membrane by quenching the anionic properties of the carboxyl group and changing the UV adsorption properties, were used. The photobactericidal activities of trans-CA derivatives were evaluated by using UV-A light (wavelength 350 to $385 \mathrm{~nm}$ ). The number of surviving Escherichia coli NBRC12713 was determined by colony-forming assay. Derivative $4 \mathrm{c}$, which was esterified with a phenyl group, reduced survival by more than $5.0-\log$ at a dose of $7.4 \mathrm{~J} / \mathrm{cm}^{2}$ and by $3.2-\log$ at a dose of $4.9 \mathrm{~J} / \mathrm{cm}^{2}$. This synergistic activity may have been caused by the absorption of photon energy from UV-A, which is attributable to the UV spectrum of 4c. The photobactericidal activity was comparable to that of riboflavin, a known photo-activated agent. Isomerized molecules serve as a promising lead for improving the photobactericidal activity of UV-A by activating molecule-mediated ROS generation.
\end{abstract}

Key words : Photobactericidal activity / p-Coumaric acid derivatives / Ultraviolet-A / Isomerizable / Reactive oxygen species.

\section{INTRODUCTION}

Resveratrol is a natural phenolic compound, belonging to the stilbene family, that exists as both trans- and cisisomers. The cis-isomer can be obtained from the trans-isomer after exposure to sunlight (Chen et al., 2007) or ultraviolet-A (UV-A) (at a wavelength of 366 $\mathrm{nm}$ ) irradiation (Basly et al., 2000). Similarly, cinnamic acid, possessing a propenoic acid moiety on a phenyl ring, produces the cis-isomer by photo-isomeric conversion after irradiation with UV light (253 nm) (Chen et al., 2011). This photoinduced isomerization plays a role in cellular responses, such as that of via rhodopsin in vision (Birge and Hubbard. 1980) and bacteriorhodopsin in photosynthesis (Mathies et al.,

\footnotetext{
*Corresponding author. Tel: +81-88-656-7519 (No FAX), E-mail : a.shirai(a)tokushima-u.ac.jp
}

1991). In a photoactive yellow protein (PYP) from purple sulfur bacterium Ectothiorhodospira halophila, trans-coumaric acid (trans-CA) linked to a cysteine in the protein is the chromophore (Hoff et al., 1994). Excitation to the $S_{1}$ state of trans-CA, the $\pi-\pi^{*}$ transition, triggers isomerization from the trans- to cis-form by absorption of photon energy during UV-A irradiation (320-400 nm) (Kort et al., 1996; Ryan et al., 2002), followed by the photo-reaction cycle of PYP. All-transretinal, the chromophore in rhodopsin and bacteriorhodopsin, in which an $\alpha, \beta$-unsaturated carbonyl group, as well as trans-CA, is part of the structure, is frequently isomerized at the $\mathrm{C}_{9}$ and $\mathrm{C}_{13}$ positions by irradiation at $380 \mathrm{~nm}$, and this is governed by both the $\pi-\pi^{*}$ and $n-\pi *$ transitions (Deval and Singh, 1988).

Recently, a novel treatment approach based on photo-chemical reactions has been introduced for the control of microbial growth and viability (Chui et al., 
2013). The photo-chemical reaction is responsible for the activation of photosensitizing agents by absorption of the appropriate wavelength, leading to the generation of reactive oxygen species (ROS) in the presence of oxygen, which disrupts the cell membrane (Giroldo et al., 2009), membrane proteins (Segalla et al., 2002) or intracellular structures (Liang et al., 2013). The photosensitizing agent is initially transformed from its $S_{0}$ ground state into the $S_{1}$ excited state by both $\pi-\pi^{*}$ and $n-\pi^{*}$ transitions or either of these transitions, which may then relax to the more long-lived $T_{1}$ state. Eventually, interaction between the excited triplet state and molecular oxygen results in the production of ROS such as superoxide and hydroxyl radicals via electron or hydrogen transfer reactions, and singlet oxygen via energy transfer (Yin et al., 2013).

The present study focused on trans-CA, which is isomerized by UV-A light. The generation of ROS was expected during the isomerization of trans-CA, which is governed by the activated excitation state. Our aim was to improve the bactericidal activity of UV-A light mediated by ROS such as hydrogen peroxide and hydroxyl radicals (Hamamoto et al., 2007) via the utilization of photo-activated compounds, in a similar way to photobactericidal agents such as riboflavin (Liang et al., 2013), methylene blue (Giroldo et al., 2009) and rose Bengal (Shrestha and Kishen, 2012). If excess ROS are produced by the combination of trans-CA and UV-A, viable cells can suffer extensive damage. To explore potential compounds, trans-CA and simple derivatives possessing photo-isomerizable moieties were used in this work. Derivatives based on trans-CA and its analogue trans-ferulic acid were synthesized in order to investigate the effects of molecular structure on antituberculosis (Yoya et al., 2009) and antimicrobial activities (Ergün et al., 2011), respectively. However, there have been (to our knowledge) few reports on the photobactericidal activity triggered by irradiation with various wavelengths. Candidates based on the transCA molecule were modified by a methyl, $n$-butyl or phenyl group at the carboxyl group in order to alter the interaction with cellular membranes by quenching the anionic properties of the carboxyl group, and to change the UV adsorption spectra. Bactericidal assays confirmed the improved bactericidal activity of UV-A light in the presence of trans-CA derivatives. The photoinduced bactericidal activity was compared with UV-Aactivated riboflavin (Makdoumi et al., 2010). The photoinduced activity of a trans-CA derivative and riboflavin was suppressed in the presence of catalase. In addition, the combination of the derivative and UV-A irradiation was found to enhance the generation of hydrogen peroxide when subject to fluorescence spectroscopic analysis. A light emitting diode (LED) emitting
UV-A light (350-385 nm) was used as the light source for the photo-reaction.

\section{MATERIALS AND METHODS}

\section{Chemistry}

All chemicals for the synthesis of compounds were commercially available, reagent-grade materials and were used without further purification. These reagents were purchased from commercial sources, including Tokyo Chemical Industry Co., Ltd., (Tokyo, Japan), Wako Pure Chemical Industries, Ltd. (Osaka, Japan), Sigma-Aldrich Co., LLC. (St. Louis, MO), Kanto Chemical Co., Inc. (Tokyo, Japan), and Merck KGaA (Darmstadt, Germany). For syntheses requiring waterfree conditions, solvents were dried using type-3A molecular sieves. Granules of sodium hydroxide were added to pyridines to ensure dryness. All reactions were monitored by thin-layer chromatography (TLC) using normal-phase (Merck silica gel $60 \mathrm{~F}_{254}$, thickness 0.25 $\mathrm{mm}$ ) and reversed-phase (Merck RP-18 $F_{254 \mathrm{~S}}$, thickness $0.25 \mathrm{~mm}$ ) thin-layer plates. NMR spectra were recorded with an NMR spectrometer (JEM-EX 400; JOEL, Tokyo, Japan) using tetramethylsilane as an internal standard. Purity of compounds was confirmed by TLC and by melting point analysis using a micromelting apparatus (Thermo Fisher Scientific, Waltham, MA). Purity also was confirmed by HPLC with UV detection (Hitachi L-2000 HPLC system equipped with a COSMOSIL column (Cholester, $4.6 \times 150 \mathrm{~mm}$ ); Hitachi High-Technologies Corporation, Tokyo, Japan) before mass analysis. Mass spectra were recorded on an LC-MS system (Acquity UPLC-LCT Premier; Nihon Waters K.K., Tokyo, Japan). Crude compounds were purified on silica gel (silica gel 120, mesh 70-230 spherical; Nacalai Tesque Inc., Kyoto, Japan) using flash column chromatography. Except for synthesis reactions performed in aqueous solutions, all reactions were conducted under a stream of nitrogen.

\section{Synthesis}

As shown in Fig.1, two trans-CA derivatives (4a-b) were synthesized by direct modification of methyl or $n$-butyl groups. Another (4c) was derived by cleavage of a protective acetyl group from the respective precursors. These synthesis methods are as described in previous reports (Ergün et al., 2011; Narasimhan et al., 2004).

The identities of all synthesized compounds were confirmed by ${ }^{1} \mathrm{H}-\mathrm{NMR}$ and mass spectrometry. The NMR spectra showed the trans $(E)$ configuration, as demonstrated by the coupling constants (ranging from 15.6 to $16.9 \mathrm{~Hz}$ ) of $a-\mathrm{H}$ and $\beta-\mathrm{H}$ on the double bond at the propenoic group. Purity of the synthesized 


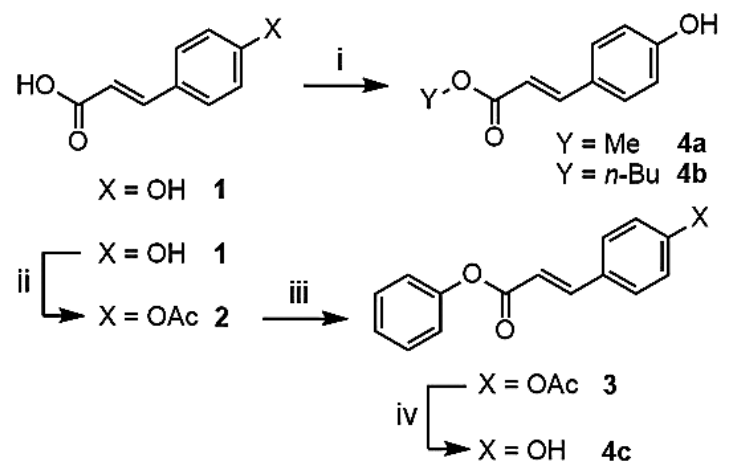

FIG. 1. Syntheses of the trans-CA derivatives (4a-c): (i) conc. $\mathrm{H}_{2} \mathrm{SO}_{4}, \mathrm{MeOH}$, reflux, $6 \mathrm{~h}, 79 \%$ (4a) or conc. $\mathrm{H}_{2} \mathrm{SO}_{4}$, $n-\mathrm{BuOH}$, reflux, $6 \mathrm{~h}, 76 \%$ (4b); (ii) acetic anhydride, pyridine, $4^{\circ} \mathrm{C}$ to rt, $3 \mathrm{~h}, 88 \%$ (2); (iii) oxalyl dichloride, phenol crystal, TEA, DMF, DCM, rt, 2 h, 86\% (3); (iv) 35\% hydrazine hydrate, AN, rt, 30 min, 80\% (4c).

compounds, as demonstrated by TLC and HPLC, was $97 \%$ or higher. Therefore, our results showed that the synthesized trans-CA derivatives were the intended compounds. Physicochemical properties such as appearance, yield, m.p., $R_{\mathrm{f}}$, and NMR and mass spectral analyses are summarized in the appendices section.

\section{(E)-3-(4-acetyloxyphenyl)-2-propenoic acid (2)}

O-Acetylation of trans-CA was performed with acetic anhydride in dried pyridine. Acetic anhydride (24.0 mmol, 3.0 equiv.) was added to a $4^{\circ} \mathrm{C}$ stirred solution of trans-CA 1 (8.00 mmol, 1.0 equiv.) in dried pyridine $(10 \mathrm{~mL})$. The solution was stirred for $3 \mathrm{~h}$ at room temperature and quenched with water, and the organic solvent in the reaction was evaporated. The purified target compound, 2, was obtained by crystallization with a mixed solution of acetone and water.

\section{(E) -phenyl 3-(4-acetyloxyphenyl)-2-propenoate (3)}

Compound (3) was synthesized by reacting the acid chlorides of compound $\mathbf{2}$ with a phenol, as described previously (Ergün et al., 2011). DMF (1.50 mmol, 0.3 equiv.) and oxalyl dichloride ( $7.50 \mathrm{mmol}, 1.5$ equiv.) were added to a mixture of $\mathbf{2}(5.00 \mathrm{mmol}, 1.0$ equiv. $)$ in $8 \mathrm{~mL}$ of dry dichlolomethane (DCM). The reaction mixture was stirred for $15 \mathrm{~min}$, and the solvent then was removed by thorough evaporation. The obtained acid chloride was again dissolved in $8 \mathrm{~mL}$ of dry DCM, and phenol crystals (10.0 mmol, 2.0 equiv.) and TEA (10.0 mmol, 2.0 equiv.) were added. The reaction was quenched with saturated ammonium chloride solution after a 2-h reaction. The DCM layer recovered from the reaction mixture was washed with brine, dried over sodium sulfate, and concentrated under reduced pres- sure. Purification by flash chromatography on silica gel using a gradient elution with $n$-hexane/ethyl acetate (8:1) yielded the intended compound (3).

\section{(E) -alkyl 3-(4-hydroxyphenyl)-2-propenoates (4a-b) and $(E)$-phenyl 3-(4-hydroxyphenyl)-2-propenoate (4c)}

Concentrated sulfuric acid ( $0.20 \mathrm{mmol}, 0.2$ equiv.) was dissolved in a mixture of trans-CA $\mathbf{1}(1.00 \mathrm{mmol}$, 1.0 equiv.) and $5 \mathrm{~mL}$ of methanol or $n$-butanol using a previously described method (Narasimhan et al., 2004). The mixture was refluxed for $6 \mathrm{~h}$ and then quenched with ice cold water. After removal of the solvent, compound $\mathbf{4 a}$ was purified by crystallization with a mixed solution of acetone and water. Compound 4b was purified by flash chromatography on silica gel using a gradient elution with $n$-hexane/ethyl acetate $(80: 1)$.

As described in a previous report, hydrazine hydrate was used for cleavage of acetyl groups from compound 3 (Ergün et al., 2011). A solution of compound 3 (3.00 mmol, 1.0 equiv.) in $5 \mathrm{~mL}$ of $\mathrm{AN}$ was combined with $35 \%$ hydrazine hydrate solution ( $3.60 \mathrm{mmol}, 1.2$ equiv.) and stirred for $30 \mathrm{~min}$. The reaction was quenched with acetic acid and water, followed by concentration by evaporation. The ethyl acetate layer was extracted from the residue and washed with brine, dried over sodium sulfate, and concentrated under reduced pressure. Purification by flash chromatography on silica gel using a gradient elution with $n$-hexane/ethyl acetate (20:1 15:1) yielded the intended compound (4c).

\section{UV-A source and irradiation}

The light source was an LED device, as described previously (Shirai et al., 2014); the spectrum and fluence rate were measured at a distance of $65 \mathrm{~mm}$ from the device (Fig.2). The fluence rate in the wavelength range (350 - $385 \mathrm{~nm}$; peak wavelength: 365 $\mathrm{nm}$ ) emitted by this device was $4.09 \mathrm{~mW} / \mathrm{cm}^{2}$. Total fluence dose was calculated based on the fluence rate and exposure time.

\section{In vitro assay for photobactericidal activity}

Bactericidal activity against Escherichia coli NBRC 12713 was determined by counting the number of colony-forming units (CFUs), as reported previously (Shirai et al., 2014); the bacterial suspension (2.0× $10^{7}$ cells $/ \mathrm{mL}$ ) was prepared as described in the same report. The suspension was distributed at $0.1 \mathrm{~mL}$ per well in 48-well culture plates (AGC Tecno Glass Co., Ltd., Tokyo, Japan) containing (per well) $0.01 \mathrm{~mL}$ of the test compound (10 mM in $80 \%$ DMSO) and $0.89 \mathrm{~mL}$ of sterile water. Plates were then incubated at $30^{\circ} \mathrm{C}$ with UV-A irradiation or with no irradiation (in a dark room). 


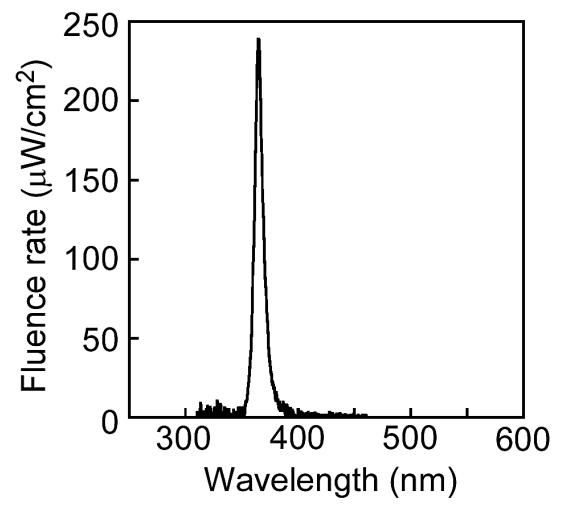

FIG. 2. Emission spectrum of UV-A-LED used in this study. This UV-A-LED provides a spectral maximum at $365 \mathrm{~nm}$. Fluence rate is $4.09 \mathrm{~mW} / \mathrm{cm}^{2}$ at a distance of $65-\mathrm{mm}$ between the illumination source and UV meter.

Aliquots $(0.15 \mathrm{~mL}$ from each well) were subjected to 10-fold dilution with SCDLP broth (Nihon Pharmaceutical Co., Ltd., Tokyo, Japan), followed by serial dilution with $0.8 \%(\mathrm{w} / \mathrm{v})$ physiological saline containing $0.7 \%(\mathrm{w} / \mathrm{w})$ Tween 80. Each serial dilution was plated on SCDLP agar (Nihon Pharmaceutical Co., Ltd.) plates, followed by incubation at $37^{\circ} \mathrm{C}$ for $48 \mathrm{~h}$. Colony counts were determined and used to calculate bactericidal activity, expressed as the log survival ratio, such that the log survival ratio $=\log \left(N_{t} / N_{0}\right)$, where $N_{0}$ was the initial colony count before bactericidal treatment and $N_{t}$ was the colony count after treatment for time $t$. Trans-CA and its derivatives (4a-c) were evaluated for their bactericidal activity, including comparison with that of riboflavin (Tokyo Chemical Industry Co., Ltd.).

In order to investigate the effects of ROS on bacterial inactivation using the combination of trans-CA derivatives and UV-A irradiation, a solution of catalase (from bovine liver; Wako Pure Chemical Industries Ltd.), dissolved in ion-exchange water, was added to the bacterial suspensions in a 48-well culture plate. The suspension was pre-incubated with bacteria at $37^{\circ} \mathrm{C}$ for 30 min before the addition of test compounds and UV-A irradiation. Catalase was added to the bacterial suspensions at final concentrations of either 100 or 200 U/well. Preliminary work (not shown) demonstrated that incubation $\left(1 \mathrm{~h}, 37^{\circ} \mathrm{C}\right.$, in the dark) with catalase resulted in a loss of viability of less than 0.1 -log. In another variation, instead of catalase, albumin (from Bovine serum, Cohn fraction V, pH 7.0; Wako Pure Chemical Industries, Ltd.) was added to the bacterial suspensions at final concentrations that were equal to the weight concentrations of catalase added.

\section{Measurement of the UV spectrum}

Solutions of trans-CA and derivative $\mathbf{4 c}$ were prepared with $80 \%(\mathrm{v} / \mathrm{v})$ DMSO at $50 \mu \mathrm{M}$ concentration. UV spectra were measured in a $1-\mathrm{cm}$ path length cuvette with a spectrophotometer (U-3300; Hitachi Ltd., Tokyo, Japan).

\section{Detection of hydrogen peroxide}

Tested trans-CA and derivative $\mathbf{4 c}$ were prepared at 1 $\mathrm{mM}$ in $80 \%$ DMSO, and then added to reaction mixtures at a final concentration of $5 \mu \mathrm{M}$. Hydrogen peroxide assay reaction ( $0.5 \mathrm{~mL} /$ well $)$ was performed at room temperature in 48-well culture plates. Reaction buffer consisted of $50 \mathrm{mM} \mathrm{Na}{ }^{+}-\mathrm{K}^{+}$phosphate ( $\mathrm{pH}$ 7.4) (P.B.). Hydrogen peroxide generation was investigated based on the fluorescence of a specific probe, BES$\mathrm{H}_{2} \mathrm{O}_{2}-\mathrm{Ac}$ (measurement wavelength; $\lambda_{\mathrm{ex}}=485 \mathrm{~nm}, \lambda_{\mathrm{em}}$ $=515 \mathrm{~nm}$; Wako Pure Chemical Industries, Ltd.), in response to peroxide (Shirai et al., 2014). The probe was formulated at $1.25 \mathrm{mM}$ in DMSO, and was then diluted in P.B. to a reaction concentration of $5 \mu \mathrm{M}$ in combination with the respective trans-CA. Following irradiation, 80- $\mu$ l aliquots were transferred to 96-well black plates (Corning Inc., Corning, NY), and fluorescence was determined with a microplate reader (Infinite M200; Tecan Japan Co., Ltd, Kanagawa, Japan). For UV-A irradiation alone (no-additive) reactions, DMSO was added to a concentration of $0.4 \%$ in combination with the probe. The positive control consisted of hydrogen peroxide at $0.5,1.0,3.0$ and $5.0 \mathrm{mM}$. As an antioxidant, $L(+)$-ascorbic acid (Kanto Chemical Co., Inc.) was added at a concentration of $40 \mathrm{mM}$ to each reaction mixture in order to quench peroxide. As a positive control, antioxidant concentration was set at $5 \mathrm{mM}$.

\section{Statistical analysis}

All experiments were performed as three independent procedures, and the results are presented as means with error bars showing standard deviation. Inferential analysis was performed using a two-tailed, unpaired Student's $t$-test. $P$ values of $<0.05$ were considered to be significant.

\section{RESULTS AND DISCUSSION}

\section{Bactericidal activity}

A combination of either parental trans-CA, its derivatives (4a-c) or riboflavin and UV-A irradiation was tested for bactericidal activity against $E$. coli using initial cell counts of $10^{6} \mathrm{CFU} / \mathrm{mL}$. Test compounds were added to concentrations of $100 \mu \mathrm{M}$. Total illumination with UV-A $\left(7.4 \mathrm{~J} / \mathrm{cm}^{2}\right)$ in the absence of exogenous compounds reduced viable cell counts by 3.6-log (Fig.3 (A)). Illumination in the presence of trans-CA yielded decreases in viable counts similar to those seen with illumination alone with increasing fluence doses 

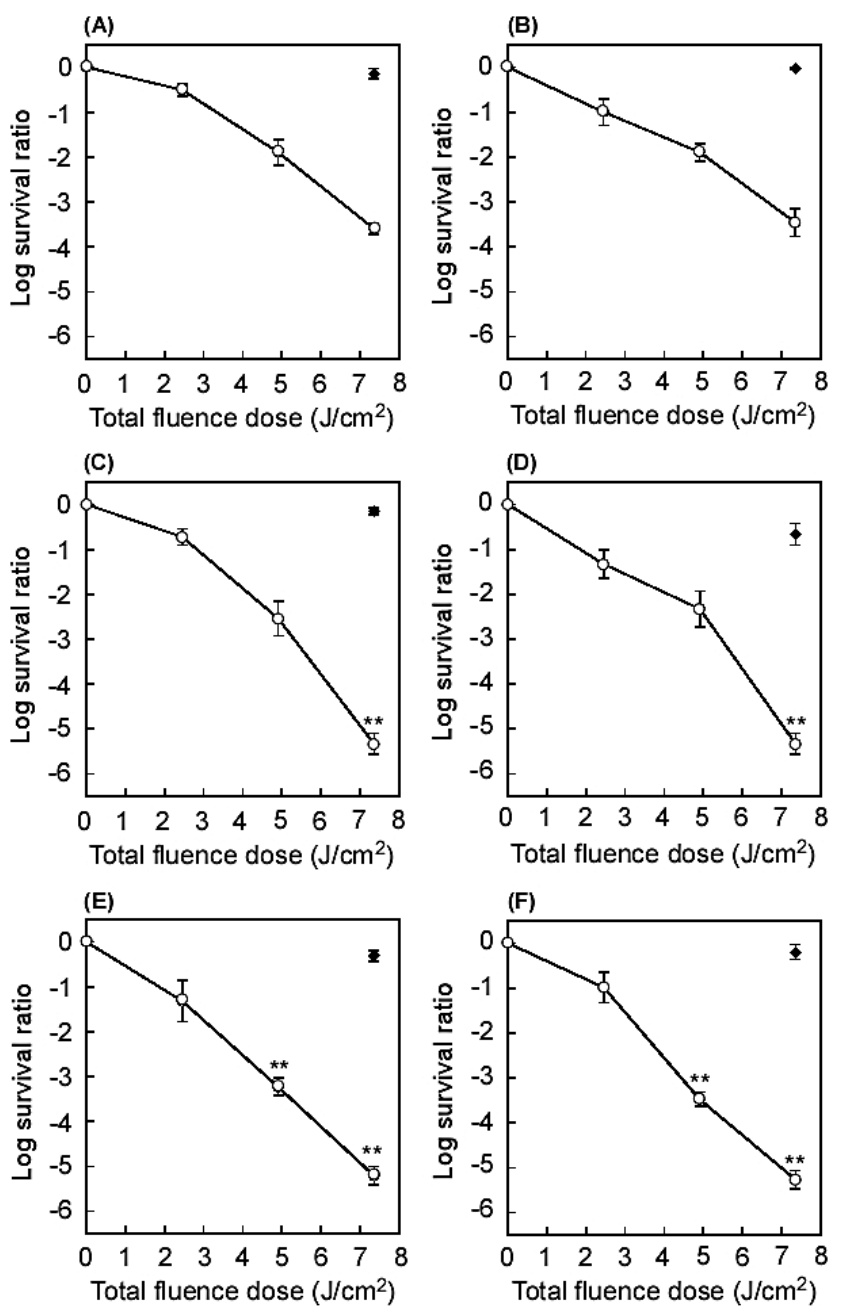

FIG. 3. Fluence dose-dependent changes in inactivation effects on $E$. coli after treatment with no-additive $(A)$, trans$C A(B), \mathbf{4 a}(C), \mathbf{4 b}(D), \mathbf{4 c}(E)$, or riboflavin (F) in combination with (unshaded) or without (shaded) UV-A irradiation. Initial cells were suspended at densities of $10^{6} \mathrm{CFU} / \mathrm{mL}$. Data are presented as means $\pm S D(n=3)$. Significant differences $\left({ }^{*} P<0.05\right.$ and $\left.{ }^{*} * 00.01\right)$ were compared to the viability after treatment with each UV-A dose without an additive.

(Fig.3 (B)). Thus, the combination of the parent with UV-A did not enhance the bactericidal activity of UV-A. In contrast, the combined use with the ester derivatives of trans-CA (4a-c) showed significant decreases in viable cells at a $7.4 \mathrm{~J} / \mathrm{cm}^{2} \mathrm{UV}$-A, as compared with UV-A alone $(P<0.01)$; viable cell counts decreased by over 5.0-log (Fig.3 (C-E)). Combining derivative 4c with a UV-A exposure at $4.9 \mathrm{~J} / \mathrm{cm}^{2}$ provided significant reductions in viable cell number (3.2-log), as compared to 1.9-log with UV-A alone $(P<0.01)$ (Fig.3 (E)). The reduction profile was comparable to that of riboflavin, which is photo-activated at $365 \mathrm{~nm}$ (Fig.3 (F)), thus demonstrating that combination with derivative $\mathbf{4 c}$,
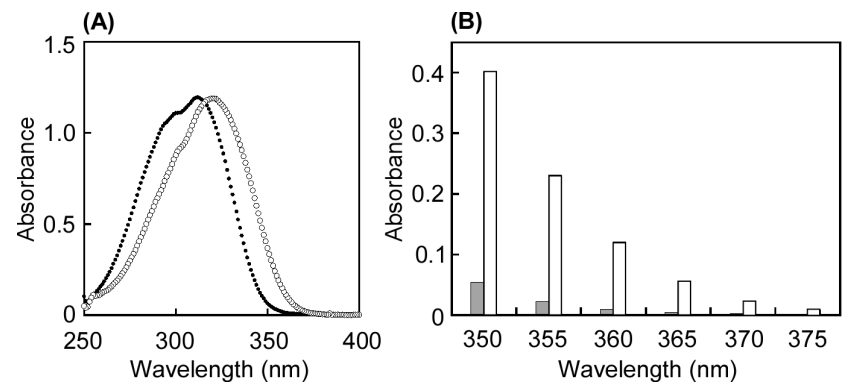

FIG. 4. Typical UV absorption spectra of $50 \mu \mathrm{M}$ trans-CA (shaded) and $\mathbf{4 c}$ (unshaded) in 80\% DMSO (A), and their absorbances, trans-CA (shaded) and 4c (unshaded), respectively, in the range of 350 to $375 \mathrm{~nm}$ (B).

especially among combined treatments, improved the bactericidal effects of UV-A in a synergistic manner. None of the five tested compounds exhibited bactericidal activity in the absence of UV-A irradiation for 30 min (incubation time corresponds to the irradiation time to provide a $7.4 \mathrm{~J} / \mathrm{cm}^{2} \mathrm{UV}$-A dose), yielding reduction of 0.67 -log for $\mathbf{4} \mathbf{b}$ and less than 0.16 -log for the others.

Inactivation of pathogens by riboflavin, using UV or visible light, is well documented and is induced by ROS. Significant non-specific oxidation formed 8-hydroxydeoxyguanosine in calf thymus DNA under UV irradiation at $355 \mathrm{~nm}$, which is similar to the peaks in the UV absorbance spectrum of riboflavin (Kumer et al., 2004). Thus, the UV spectra of the most potent photobactericidal derivative, $\mathbf{4 c}$, and parental trans-CA were measured. The maximum absorbances for parental trans-CA and 4c were 1.195 and 1.189, respectively, which corresponded to wavelengths of 312 and 321 $\mathrm{nm}$ (Fig.4 (A)). The shift toward longer wavelengths resulted from modification of the phenyl group in the parental CA. The absorbances for both CAs in the range of 350 to $370 \mathrm{~nm}$, the emission range of the present UV-A LED, were extracted from Fig.4 (A) (Fig.4 (B)). There were significant differences in absorbance; the parental CA scarcely absorbed light in this range, whereas derivative $\mathbf{4 c}$ absorbed it strongly. This suggests that the derivative acts as a photo-activated agent with UV-A light, thus elevating ROS production during the photosensitization process.

Proanthocyanidin irradiated at $365 \mathrm{~nm}$ generates hydroxyl and superoxide radicals more effectively than with visible light (Nakumura et al., 2013). ROS generation is dependent on the wavelength at which the compound shows high absorbance, thus suggesting that the photo-reaction is caused by absorbed photon energy. Simple molecules, such as $\mathbf{4 c}$, with a photoisomerizable moiety such as trans-CA, may therefore be promising for the development of new photosensitizers to improve the photobactericidal effects of UV-A light. In 


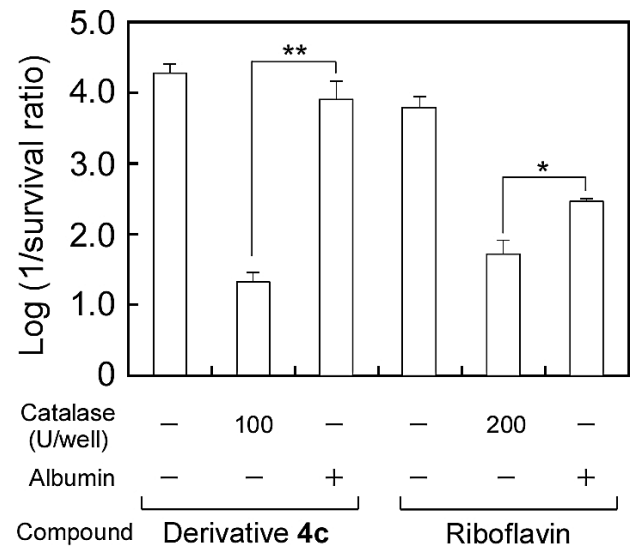

FIG. 5. Effects of ROS on the inactivation of $E$. coli by the combination of $100 \mu \mathrm{M}$ of either derivative (4c) or riboflavin with a fluence dose of $4.9 \mathrm{~J} / \mathrm{cm}^{2} \mathrm{UV}-\mathrm{A}$. Cell suspensions (initial density, $10^{6} \mathrm{CFU} / \mathrm{mL}$ ) were pretreated $\left(30\right.$ min at $37^{\circ} \mathrm{C}$ ) with catalase (100 or $200 \mathrm{U} /$ well) or with equivalent concentrations of albumin. Data are presented as means $\pm S D(n=$ 3). Significant differences are shown as $P<0.05\left({ }^{*}\right)$ and $P<0.01(* *)$.

a future study, trans-ferulic acid, which is an analogue of trans-CA, will be examined as a new photo-agent, as the compound has almost the same UV absorption properties as derivative $\mathbf{4 c}$, showing maximum absorbance ( $\mathrm{ABS}=0.958$ ) at $325 \mathrm{~nm}$ (data not shown).

\section{Effects of ROS on the bactericidal mechanism}

ROS was presumed to contribute to the synergistic anti-bacterial effects observed with the combination of derivative $\mathbf{4 c}$ and UV-A treatment. Production of hydrogen peroxide was estimated in the presence of derivative $\mathbf{4 c}$ upon UV-A photo-activation. The role of hydrogen peroxide was investigated in $E$. coli treated by the combination of $\mathbf{4 c}(100 \mu \mathrm{M})$ and $4.9 \mathrm{~J} / \mathrm{cm}^{2}$ of UV-A, as compared with riboflavin photo-activated under the same conditions. Figure 5 shows survival ratios after the combined treatment in the presence and absence of catalase. Addition of catalase significantly attenuated bacterial cell death for the derivative $\mathbf{4 c}$ from 4.2-log to 1.3-log. Exposure to an equivalent weight concentration of non-enzymatic albumin indicated high bactericidal activity $(P<0.01)$, demonstrating that attenuation was related to the enzymatic decomposition of hydrogen peroxide. The effects of these substances on bactericidal activity was identical to those in the case of riboflavin (at $100 \mathrm{U} /$ well catalase, although the data are not shown, the inhibition of bactericidal activity by riboflavin was observed to be less than that of $200 \mathrm{U} /$ well and the difference in log survival ratios with or without catalase was one order of magnitude). Based on these results, we believe that the presence of ROS such as hydrogen peroxide contributed to the syner-

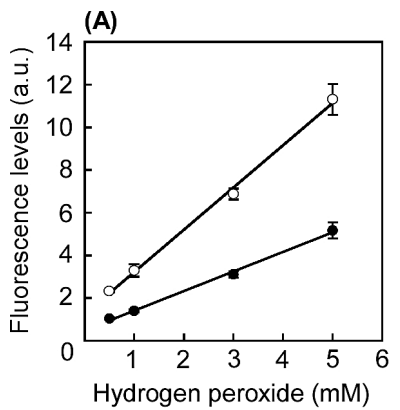

(B)

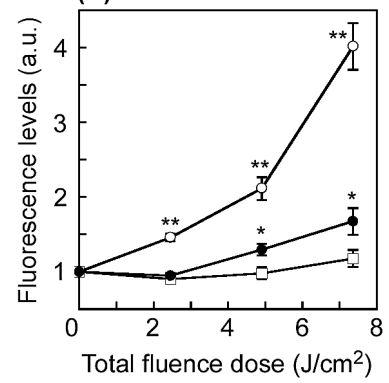

FIG. 6. Dose-dependent changes in fluorescence levels from a specific fluorescence probe reacting with hydrogen peroxide. (A) Fluorescence intensity was measured during a 30-min reaction with hydrogen peroxide in the dark, with (shaded) or without (unshaded) $L(+)$-ascorbic acid. Fluorescence levels for each concentration are expressed as the a.u. of fluorescence, as compared to the intensity obtained before addition of peroxide: (unshaded) a.u. $=1.25$ $+1.98 \times$ (hydrogen peroxide conc.) $(r=0.999)$; (shaded) a.u. $=0.497+0.918 \times$ (hydrogen peroxide conc. $)(r=$ 0.999). (B) Fluorescence levels are shown against the total fluence dose of UV-A. Shaded or unshaded circles indicate treatment with derivative $\mathbf{4 c}$, with or without $L(+)$-ascorbic acid, respectively. Levels with UV-A treatment alone are shown as unshaded squares. Levels for each treatment are expressed as the a.u. of fluorescence, as compared to the values obtained from each sample before irradiation. Data are presented as means $\pm S D(n=3) .{ }^{*} P<0.05$ and ${ }^{*} P<0.01$, as compared to each sample before irradiation.

gistic efficacy of the combined treatment procedures.

\section{Generation of ROS by UV-A irradiation}

Photo-isomerization of trans-CA modified with phenyl groups (4c) was investigated by ${ }^{1} \mathrm{H}-\mathrm{NMR}$ analysis, as described previously (Kort et al., 1996). At a dose of $7.4 \mathrm{~J} / \mathrm{cm}^{2}$ from the present UV-A device, the derivative (tested at $1 \mathrm{mM}$ in DMSO- $\mathrm{d}_{6}$ ) isomerized to cis-isomer at a ratio of $35 \%$ (data not shown). Excitation of the derivative by UV-A light may be due to the transfer of an electron to molecular oxygen in order to generate superoxide radicals, followed by hydrogen peroxide, as ROS were detected as an excited unsaturated fatty acid ester following UV-A illumination (Xia et al., 2006). Production of hydrogen peroxide was estimated in the presence of derivative $\mathbf{4 c}$, which showed the highest bactericidal activity upon UV-A photo-activation.

Reactivity of the fluorescence probe used with hydrogen peroxide depended linearly on concentration. Addition of ascorbic acid as an antioxidant interrupted fluorescence (Fig.6 (A)). Generation of hydrogen peroxide was investigated with or without derivative $\mathbf{4 c}$. As shown in Fig.6 (B), the combination of $\mathbf{4 c}$ and UV-A light resulted in a large and significant $(P<0.01)$ increase in fluorescence levels, which were dependent 
on fluence dose, thus suggesting the production of peroxide. In the dark, $\mathbf{4 c}$ maintained its initial fluorescence intensity during the measurement period (data not shown). UV-A alone scarcely induced fluorescence. On irradiation in the presence of $\mathbf{4 c}$, the inclusion of antioxidant clearly suppressed the increase in fluorescence. Trans-CA scarcely affected the bactericidal activity of UV-A (Fig.3 (A)) and the fluorescence profile was similar to that seen with the addition of antioxidant (data not shown). The combination of derivative $\mathbf{4 c}$ and UV-A clearly increased hydrogen peroxide levels in solution.

Excess ROS generation, causing oxidative damage to bacterial cellular components, may be responsible for the observed bactericidal activity. We believe that ROS production results from electron or hydrogen transfer to molecular oxygen by mediating activation of photoexcited derivatives. Specifically, 4c might show synergy with UV-A with regard to the generation of ROS. Hydroxyl radicals are typically a short-lived and strongly oxidative species; presumably, radicals could be produced by photolysis of hydrogen peroxide. In this work, the production of hydrogen peroxide was estimated based on relative changes in fluorescence intensity. However, other major ROS such as superoxide radicals and singlet oxygen were not specifically detected by spectroscopic methods. A more direct ROS assay using the electron spin resonance method would permit such qualitative and quantitative analyses (Nakamura et al., 2013).

\section{CONCLUSION}

We explored the application of trans-CA and its derivatives incorporating a photo-isomerizable molecule to photo-activated sterilization. The intent was to develop new photo-activated agents to improve the bactericidal activity by UV-A-triggered photo-reactions. The bactericidal activity of trans-CA derivatives, including the parent, was investigated in combination with UV-A illumination. A trans-CA derivative (4c) substituted with a phenyl group exhibited significantly higher bactericidal activity when combined with UV-A exposure. The synergistic activity could be caused by ROS production after absorption of UV light energy. The suppression of bactericidal activity with the addition of catalase and the production of hydrogen peroxide, as detected by fluorescence spectroscopy, suggest that photo-activation of the derivative results in excess ROS production, which may provide a mechanism for the bactericidal activity.

\section{ACKNOWLEDGMENT}

This work was supported by a Grant-in-Aid for Young Scientists (B) from the Japan Society for the Promotion of Science (no. 25870476).

\section{APPENDICES}

(E) -3-(4-Acetyloxyphenyl) -2-propenoic acid (2) White crystal; yield, 88.0\%; m.p., 217-220 $\mathrm{C}$; $R_{\mathrm{f}}$ with $\mathrm{SiO}_{2}$-TLC ( $n$-hexane : ethyl acetate $\left.=2: 1, \mathrm{v} / \mathrm{v}\right), 0.18$; ${ }^{1} \mathrm{H}-\mathrm{NMR}\left(400 \mathrm{MHz}, \mathrm{CD}_{3} \mathrm{OD}, \delta\right.$ in ppm): 2.28 (s, 3H, $\left.\mathrm{CH}_{3}\right), 6.51(\mathrm{~d}, 1 \mathrm{H}, \mathrm{J}=15.9 \mathrm{~Hz}$, ethylene $a-\mathrm{CH}), 7.18$ $(\mathrm{d}, 2 \mathrm{H}, J=8.6 \mathrm{~Hz}$, 4-acetyloxyphenyl group $\beta-\mathrm{CH}$ ), $7.59(\mathrm{~d}, 1 \mathrm{H}, \mathrm{J}=15.6 \mathrm{~Hz}$, ethylene $\beta-\mathrm{H}), 7.74(\mathrm{~d}, 2 \mathrm{H}$, $J=8.6 \mathrm{~Hz}, 4$-acetyloxyphenyl group $a-\mathrm{CH})$; ESI-MS $(\mathrm{m} / \mathrm{z})$ for $\mathrm{C}_{11} \mathrm{H}_{10} \mathrm{O}_{4}$, calculated: $206.06[\mathrm{M}]^{+}$, found: $207.067[\mathrm{M}+\mathrm{H}]^{+}$.

\section{(E)-Phenyl 3-(4-acetyloxyphenyl)-2-propenoate} (3)

White crystal; yield, $86.2 \%$; m.p., $113-114^{\circ} \mathrm{C}$; $R_{\mathrm{f}}$ with $\mathrm{SiO}_{2}$-TLC ( $n$-hexane : ethyl acetate $\left.=4: 1 \mathrm{v} / \mathrm{v}\right), 0.34$; ${ }^{1} \mathrm{H}-\mathrm{NMR}\left(400 \mathrm{MHz}, \mathrm{CDCl}_{3}, \delta\right.$ in ppm) : 2.33 (s, 3H, $\left.\mathrm{CH}_{3}\right), 6.59(\mathrm{~d}, 1 \mathrm{H}, \mathrm{J}=16.0 \mathrm{~Hz}$, ethylene $a-\mathrm{CH}), 7.17$ ( $\mathrm{m}, 4 \mathrm{H}$, 4-acetyloxyphenyl group $\beta-\mathrm{CH}$ and $\mathrm{Ar}$ group $a-\mathrm{CH}), 7.25(\mathrm{t}, 1 \mathrm{H}, J=7.3 \mathrm{~Hz}$, Ar group $\gamma-\mathrm{CH})$, $7.41(\mathrm{t}, 2 \mathrm{H}, J=7.8 \mathrm{~Hz}$, Ar group $\beta-\mathrm{CH}), 7.61(\mathrm{~d}, 2 \mathrm{H}$, $J=8.2 \mathrm{~Hz}$, 4-acetyloxyphenyl group $a-\mathrm{CH}), 7.85$ (d, $1 \mathrm{H} \mathrm{J}=15.6 \mathrm{~Hz}$, ethylene $\beta-\mathrm{H})$; ESI-MS $(\mathrm{m} / \mathrm{z})$ for $\mathrm{C}_{17} \mathrm{H}_{14} \mathrm{O}_{4}$, calculated: $282.09[\mathrm{M}]^{+}$, found: 283.103 $[\mathrm{M}+\mathrm{H}]^{+}$.

\section{(E) -Methyl 3-(4-hydroxyphenyl)-2-propenoate (4a)}

White crystal; yield, $79.2 \%$; m.p., $144-145^{\circ} \mathrm{C}$; $R_{\mathrm{f}}$ with $\mathrm{SiO}_{2}$-TLC ( $n$-hexane : ethyl acetate $\left.=2: 1 \mathrm{v} / \mathrm{v}\right), 0.50$; ${ }^{1} \mathrm{H}-\mathrm{NMR}\left(400 \mathrm{MHz}, \mathrm{DMSO}-\mathrm{d}_{6}, \delta\right.$ in ppm) : 3.81 (s, $\left.3 \mathrm{H}, \mathrm{CH}_{3}\right), 6.30(\mathrm{~d}, 1 \mathrm{H}, J=16.3 \mathrm{~Hz}$, ethylene $a-\mathrm{CH})$, $6.86(\mathrm{~d}, 2 \mathrm{H}, \mathrm{J}=8.6 \mathrm{~Hz}$, 4-hydroxyphenyl group $\beta$ $\mathrm{CH}), 7.42(\mathrm{~d}, 2 \mathrm{H}, J=8.6 \mathrm{~Hz}$, 4-hydroxyphenyl group $a-\mathrm{CH}), 7.64(\mathrm{~d}, 1 \mathrm{H}, J=15.9 \mathrm{~Hz}$, ethylene $\beta-\mathrm{H})$; ESI-MS $(\mathrm{m} / \mathrm{z})$ for $\mathrm{C}_{10} \mathrm{H}_{10} \mathrm{O}_{3}$, calculated: $178.06[\mathrm{M}]^{+}$, found: $179.071[\mathrm{M}+\mathrm{H}]^{+}$.

(E) -Butyl 3- (4-hydroxyphenyl) -2-propenoate (4b)

Yellowish crystal; m.p., $82-85^{\circ} \mathrm{C}$; yield, $76 \% ; R_{\mathrm{f}}$ with $\mathrm{SiO}_{2}$-TLC ( $n$-hexane : ethyl acetate $\left.=2: 1 \mathrm{v} / \mathrm{v}\right): 0.6$; ${ }^{1} \mathrm{H}-\mathrm{NMR}\left(400 \mathrm{MHz}, \mathrm{CDCl}_{3}, \delta\right.$ in ppm): 0.96 (t, 3H, J $=7.47 \mathrm{~Hz}, n$-butyl group $\left.\mathrm{CH}_{3}\right), 1.43(\mathrm{~m}, 2 \mathrm{H}, n$-butyl group $\left.\mathrm{CH}_{2}\right), 1.69\left(\mathrm{~m}, 2 \mathrm{H}, n\right.$-butyl group $\left.\mathrm{CH}_{2}\right) 4.19(\mathrm{~s}$, $2 \mathrm{H}, n$-butyl group $\mathrm{CH}_{2}$ ), $5.17(\mathrm{~s}, 1 \mathrm{H}, \mathrm{OH}), 6.30(\mathrm{~d}$, $1 \mathrm{H}, J=15.9 \mathrm{~Hz}$, ethylene $a-C H), 6.83(d, 2 \mathrm{H}, J=8.6$ $\mathrm{Hz}$, 4-hydroxyphenyl group $a-\mathrm{CH}), 7.43(\mathrm{~d}, 2 \mathrm{H}, \mathrm{J}=$ 
$9.0 \mathrm{~Hz}$, 4-hydroxyphenyl group $\beta-\mathrm{CH}), 7.62(\mathrm{~d}, 1 \mathrm{H}, J$ $=15.9 \mathrm{~Hz}$, ethylene $\beta-\mathrm{H})$; ESI-MS $(\mathrm{m} / \mathrm{z})$ for $\mathrm{C}_{13} \mathrm{H}_{16} \mathrm{O}_{3}$, calculated: $220.11[\mathrm{M}]^{+}$, found: $221.118[\mathrm{M}+\mathrm{H}]^{+}$.

\section{(E) -Phenyl 3-(4-hydroxyphenyl)-2-propenoate (4c)}

White crystal; yield, $80 \%$; m.p., $144-146^{\circ} \mathrm{C}$; $R_{\mathrm{f}}$ with $\mathrm{SiO}_{2}-\mathrm{TLC}(n$-hexane : ethyl acetate $=4: 1 \mathrm{v} / \mathrm{v}), 0.21$; ${ }^{1} \mathrm{H}-\mathrm{NMR}\left(400 \mathrm{MHz}, \mathrm{CD}_{3} \mathrm{OD}, \delta\right.$ in ppm): $6.53(\mathrm{~d}, 1 \mathrm{H}$, $J=16.3 \mathrm{~Hz}$, ethylene $a-\mathrm{CH}), 6.84(\mathrm{~d}, 2 \mathrm{H}, J=8.6 \mathrm{~Hz}$, 4-hydroxyphenyl group $\beta-\mathrm{CH}), 7.14(\mathrm{~d}, 2 \mathrm{H}, \mathrm{J}=8.2$ $\mathrm{Hz}$, Ar group $a-\mathrm{CH}), 7.24(\mathrm{~m}, 1 \mathrm{H}, J=7.5 \mathrm{~Hz}, \mathrm{Ar}$ group $\gamma-\mathrm{CH}), 7.41(\mathrm{t}, 2 \mathrm{H}, \mathrm{J}=7.9 \mathrm{~Hz}$, Ar group $\beta$ $\mathrm{CH}), 7.54(\mathrm{~d}, 2 \mathrm{H}, J=8.6 \mathrm{~Hz}$, 4-hydroxyphenyl group $a-\mathrm{CH}), 7.80(\mathrm{~d}, 1 \mathrm{H}, J=15.9 \mathrm{~Hz}$, ethylene $\beta-\mathrm{H})$; ESI-MS $(\mathrm{m} / \mathrm{z})$ for $\mathrm{C}_{15} \mathrm{H}_{12} \mathrm{O}_{3}$, calculated: $240.08[\mathrm{M}]^{+}$, found: $241.087[\mathrm{M}+\mathrm{H}]^{+}$.

\section{REFERENCES}

Basly, J.-P., Marre-Fournier, F., Le Bail, J.-C., Habrioux, G., and Chulia, A. J. (2000) Estrogenic/antiestrogenic and scavenging properties of $(E)$ - and $(Z)$-resveratrol. Life Sciences, 66, 769-777.

Birge, R. R., and Hubbard Lynn M. (1980) Molecular dynamics of cis-trans isomerization in rhodopsin. J. Am. Chem. Soc., 102, 2195-2205.

Chen, X., He, H., Wang, G., Yang, B., Ren, W., Ma, L., and Yu, Q. (2007) Stereospecific determination of cis- and trans-resveratrol in rat plasma by HPLC: application to pharmacokinetic studies. Biomed. Chromatogr., 21, 257-265.

Chen, Y.-L., Huang, S.-T., Sun, F.-M., Chiang, Y.-L., Chiang, C.-J., Tsai, C.-M., and Weng, C.-J. (2011) Transformation of cinnamic acid from trans- to cis-form raises a notable bactericidal and synergistic activity against multiple-drug resistant Mycobacterium tuberculosis. Eur. J. Pharm. Sci., 43, 188-194.

Chui, C., Aoki, A., Takeuchi, Y., Sasaki, Y., Hiratsuka, K., Abiko, Y., and Izumi, Y. (2013) Antimicrobial effect of photodynamic therapy using high-power blue light-emitting diode and red-dye agent on Porphyromonas gingivalis. J. Periodont. Res., 48, 696-705.

Deval, P., and Singh, A.K. (1988) Photoisomerization of alltrans-retinal in organic solvents and organized media. J. Photochem. Photobiol. A., 42, 329-336.

Ergün, B. Ç., Çoban, T., Onurdag, F. K., and Banoglu, E. (2011) Synthesis, antioxidant and antimicrobial evaluation of simple aromatic esters of ferulic acid, Arch. Pharm. Res. 34, 1251-1261.

Giroldo, L. M., Felipe, M. P., de Oliveira, M. A., Munin, E., Alves, L. P., and Costa, M. S. (2009) Photodynamic antimicrobial chemotherapy (PACT) with methylene blue increases membrane permeability in Candida albicans. Lasers in Med. Sci., 24, 109-112.

Hamamoto, A., Mori, M., Takahashi, A., Nakano, M., Wakikawa, N., Akutagawa, M., Ikehara, T., Nakaya, Y., and Kinouchi, Y. (2007) New water disinfection system using UVA light-emitting diodes, J. Appl. Microbiol., 103 2291-2298.

Hoff, W. D., Dux, P., Hard, K., Devreese, B., Nugteren-
Roodzant, I.M., Crielaard, W., Boelens, R., Kaptein, R., Van Beeumen, J., and Hellingwerf, K. J. (1994) Thiol esterlinked $p$-coumaric acid as a new photoactive prosthetic group in a protein with rhodopsin-like photochemistry. Biochemistry, 33, 13959-13962.

Kort, R., Vonk, H., Xu, X., Hoff, W. D., Crielaard, W., Hellingwerf, K. J. (1996) Evidence for trans-cis isomerization of the $p$-coumaric acid chromophore as the photochemical basis of the photocycle of photoactive yellow protein. FEBS Lett., $\mathbf{3 8 2}$, 73-78.

Kumar, V., Lockerble, O., Kell, S. D., Ruane, P. H., Platz, M. S., Martin, C. B., Ravanat, J.-L., Cadet, J., and Goodrich, R. P. (2004) Riboflavin and UV-light based pathogen reduction: Extent and consequence of DNA damage at the molecular level. Photochem. Photobiol., 80, 15-21.

Liang, Ji-Y., Yuann, Jeu-M. P., Cheng, C.-W., Jian, H.-L., Lin, C.-C., and Chen, L.-Y. (2013) Blue light induced free radicals from riboflavin on E. coli DNA damage. J. Photochem. Photobiol. B., 119, 60-64.

Makdoumi, K., Bäckman, A., Mortensen, J., and Crafoord, S. (2010) Evaluation of antibacterial efficacy of photo-activated riboflavin using ultraviolet light (UVA). Graefes Arch. Clin. Exp. Ophthalmol., 248, 207-212.

Mathies, R. A., Lin, S. W., Ames, J. B., and Pollard, W. T. (1991) From femtoseconds to biology: Mechanism of bacteriorhodopsin's light-driven proton pump. Annu. Rev. Biophys. Biohys. Chem., 20, 491-518.

Nakamura, K., Shirato, M., Ikai, H., Kanno, T., Sasaki, K., Kohno, M., and Niwano Y. (2013) Photo-irradiation of proanthocyanidin as a new disinfection technique via reactive oxygen species formation. PloS one, 8, e60053.

Narasimhan, B., Belsare, D., Pharande, D., Mourya, V., and Dhake, A. (2004) Esters, amides and substituted derivatives of cinnamic acid: synthesis, antimicrobial activity and QSAR investigations, Eur. J. Med. Chem., 39, 827-834.

Ryan, W. L., Gordon, D. J., and Levy, D. H. (2002) Gas-phase photochemistry of the photoactive yellow protein chromophore trans-p-coumaric acid. J. Am. Chem. Soc., 124, 6194-6201.

Segalla, A., Borsarelli, C. D., Braslavsky, S. E., Spikes, J. D., Roncucci, G., Dei, D., Chiti, G., Jori, G., and Reddia, E. (2002) Photophysical, photochemical and antibacterial photosensitizing properties of a novel octacationic $\mathrm{Zn}$ (II) -phthalocyanine. Photochem. Photobiol. Sci., 1, 641-648.

Shirai, A., Aihara, M., Takahashi, A., Maseda, H., and Omasa, T. (2014) Synergistic antimicrobial activity based on the combined use of a gemini-quaternary ammonium compound and ultraviolet-A light, J. Photochem. Photobiol. B., 130, 226-233.

Shrestha, A., and Kishen, A. (2012) Polycationic chitosanconjugated photosensitizer for antibacterial photodynamic therapy. Photochem. Photobiol., 88, 577-583.

Xia, Q., Yin, J. J., Cherng, S.-H., Wamer, W. G., Boudreau, M., Howard, P. C., and Fu, P. P. (2006) UVA photoirradiation of retinyl palmitate-Formation of singlet oxygen and superoxide, and their role in induction of lipid peroxidation, Toxicol. Lett., 163, 30-43.

Yin, R., Dai, T., Avci, P., Jorge, A. E. S., de Melo W. CMA, Vecchio, D., Huang, Y.-Y., Gupta, A., and Hamblin, M.R. (2013) Light based anti-infectives: ultraviolet C irradiation, photodynamic therapy, blue light, and beyond. Curr. Opin. Pharmacol., 13, 731-762.

Yoya, G. K., Bedos-Belval, F., Constant, P., Duran, H., Daffé, M., and Baltas, M. (2009) Synthesis and evaluation of a novel series of pseudo-cinnamic derivatives as antituberculosis agents, Bioorg. Med. Chem. Lett., 19, 341-343. 